\title{
HUKUMAN HAD BAGI SESEORANG YANG MENYETUBUHI WANITA AJNABIAH MELALUI DUBUR PERSPEKTIF SYAFI'IAH
}

\author{
Muhammad Alwin Abdillah \\ Dosen Tetap Prodi Hukum Pidana Islam (Jinayah) \\ Fakultas Syariah IAIN Langsa
}

\begin{abstract}
ABSTRAK
Tulisan ini membahas tentang hukuman had bagi seseorang yang menyetubuhi wanita ajnabiah melalui dubur perspektif Syafi'iah. Imam Syafi'I sendiri tidak memberikan pendapat langsung terkait permasalahan ini. Namun, ulama syafi'ah menganggapi pesoalan tersebut, dimana mayoritas ulama syafi' iah menyamakan persetuhan yang dilakukan dari dubur dengan persetubuhan yang dilakukan melalui dubur wanita ajnabiah. Metode yang mereka gunakan adalah metode qiyas, dimana menurut mereka; keduanya (perzinahan melalui qubul ataupun dubur) menghasilkan syahwat dan keduanya pula merupakan bahagian tubuh yang harus ditutupi dan di jaga oleh seorang wanita.demikian pula wajib mandi bagi laki - laki yang memasukkan kemaluannya pada salah satu dari keduanya (qubul dan dubur).
\end{abstract}

Kata Kunci: hukuman had, anal sex without marriage, perspektif Syariah, perspektif Syafi'iah

This paper discusses the punishment for someone who has intercourse with an ajnabiah woman through the anal perspective of Shafi'iah. Imam Shafi'I himself did not give a direct opinion related to this issue. However, Shafi'i clerics address the problem, where the majority of Shafi'i clerics equate the intercourse done from the rectum with the intercourse done through the rectal female Ajnabiah. The method they use is the qiyas method, which according to them; both (adultery through qubul or rectum) produce lust and both are parts of the body that must be covered and guarded by a woman. Likewise, mandatory bathing for men who put their genitals in one of them (qubul and rectum).

Keywords: had punishment, anal sex without marriage, Shariah perspective, Syafi' iah perspective.

\section{A. PENDAhuluan}

Zina adalah setiap

persetubuhan yang terjadi bukan

karena pernikahan yang sah, bukan karena syubhat, dan bukan pula karena pemilikan (budak). Secara garis besar pengertian ini telah disepakati oleh para ulama ${ }^{e e}$ Islam, 
meskipun mereka masih berselisih pendapat tentang penerapan hukumannya. ${ }^{1} \quad$ Maraknya kasus perzinaan yang terjadi dan terus meningkat pada kalangan anak-anak muda bahkan juga orang yang sudah menikah sangatlah meresahkan masyarakat. Karena hal itu dikhawatirkan akan merusak moral seseorang. Disamping rusaknya moral sesorang, dengan terjadinya kasus perzinaan yang terus meningkat ditakutkan akan menimbukan beberapa penyakit diantaranya HIV, AIDS, Sipilis dan lain sebagainya. Dan jika hal itu sudah terjadi, tentunya saja orang yang merasa dirugikan bukan hanya si pelaku, namun orang disekitarnya pasti merasa dirugikan. Apalagi jika si pelaku tertangkap tangan dalam melakukan perzinaan ataupun terkena penyakit dari apa yang telah dia lakukan, pasti keluarga, daerah, bahkan kerabat-kerabatnya akan merasa malu dan terbebani atas apa yang telah dia lakukan. Belum lagi

\footnotetext{
1)Zainudin Ali, Hukum Pidana Islam, (Jakarta: Sinar Grafika, 2009), hlm. 37.
}

kalau dari apa yang telah dia lakukan bisa menimbulkan lahirnya seseorang, tentunya orang yang lahir dari hubungan perzinaan akan merasa malu dan tidak jelas nasab serta keturunannya.

Dewasa ini banyak ditemukan para remaja yang menyetubuhi teman wanitanya dengan cara anal sex (bersetubuh melalui lubang dubur). Hal ini mereka lakukan karena tidak akan dapat menyebabkan kehamilan dab banyak pula dari mereka yang menganggap bahwa menyetubuhi wanita melalui dubur bukanlah perbuatan zina.

Berdasarkan penjelasan di atas penulis merasa penting untuk membahas lebih komprehensif mengenai hukuman had bagi seseorang yang menyebuhi wanita ajnabiah melalui dubur perspektif madzhab Syafi'iah.

\section{B. BIOGRAFI IMAM SYAFI'I}

\section{Latar Belakang Keluarga}

Imam Syafi'i adalah salah seorang ulama yang sangat masyhur. Setiap orang yang 
memperhatikannya akan tertarik untuk mengetahui lebih dalam pribadinya, perilakunya serta peninggalannya yang telah membuat orang yang memperhatikannya menghormati, memuliakan dan mengagungkannya. ${ }^{2}$ Nama lengkap Imam Syafi'i adalah Muhammad Ibn Idris Ibn al-Abbas Ibn Syafi'i Ibn alSa ${ }^{e e} i b$ Ibn Ubaid Ibn Abd Yazid Ibn Hasyim Ibn Abd al-Muthalib Ibn Abd Manaf. ${ }^{3}$ Lahir di Ghaza (suatu daerah dekat Palestina) pada tahun $150 \mathrm{H}$, kemudian dibawa oleh ibunya ke Makkah. Beliau lahir pada zaman Dinasti Bani Abbas, tepatnya pada zaman kekuasaan Abu Ja"far alManshur (137-159 H./754-774 M), dan ia meninggal di Mesir pada tahun $204 \mathrm{H}^{4}$

Imam Syafi'i berasal dari

2)Mustofa Muhammad asy-Syak"ah, Islam bi Laa Madzzhib, Terj. A.M. Basamalah, Islam Tidak Bermadzhab, (Jakarta: Gema Insani Press, 1994), hlm. 349.

3)Jaih mubarok, Sejarah dan Perkembangan Hukum Islam, ( Bandung: PT Remaja Rosdakarya, 2000), h.101. Lihat juga Abdul Mun "im Saleh, Madzhab Syafi" $i$ Kajian Konsep al-Maslahah, (Yogyakarta: Ittaqa Press, 2001), hlm.7. Lihat juga Ali Fiqri, Kisahkisah Para Imam Madzhab, (Yogyakarta: Mitra Pustaka, 2003), hlm.76.

4)Jaih Mubarok, Modifikasi Hukum Islam Studi tentang Qaul Qadim dan Qaul Jadid, (Jakarta: PT. Raja Grafindo Persada, 2002), hlm.27. keturunan bangsawan yang paling tinggi di masanya. Walaupun hidup dalam keadaan sangat sederhana, namun kedudukannya sebagai putra bangsawan, menyebabkan ia terpelihara dari perangai-perangai buruk. Tidak mau merendahkan diri dan berjiwa besar. Ia bergaul rapat dalam masyarakat dan merasakan penderitaan- penderitaan mereka. Imam Syafi'i dengan usaha ibunya telah dapat menghafal al-Qur'an dalam umur yang masih sangat muda. Kemudian ia memusatkan perhatian menghafal hadits. Ia menerima hadits dengan jalan membaca dari atas tembikar dan kadang-kadang di kulit binatang. Seringkali pergi ke tempat pembuangan kertas untuk memilih mana-mana yang masih dapat digunakan. $^{5}$

Kata Syafi'i dinisbatkan kepada nama kakeknya yang ketiga, yaitu Syafi'i Ibn al-Saib, ayahnya bernama Idris Ibn Abbas Ibn Usman Ibn Syafi'i Ibn al-Saib Ibn Abdul

5)Mahmud Syalthut, Fiqih Tujuh Madzhab, terj. Abdullah Zakiy al- Kaaf, (Bandung: Pustaka Setia, 2000), hlm.17. 
Manaf, sedangkan ibunya bernama Fatimah Ibnti Abdullah Ibn alHasan Ibn Husain Ibn Ali Ibn Abi Thalib, dari garis keturunan ayahnya, Imam Syafi'i bersatu dengan keturunan Nabi Muhammad SAW. Pada Abdul Manaf, kakek Nabi SAW yang ketiga, sedangkan dari pihak ibunya, beliau adalah cicit dari Ali Ibn Thalib. Dengan demikian, kedua orang tuanya berasal dari bangsawan Arab Quraisy. ${ }^{6}$

Keluarga Imam Syafi'i adalah dari keluarga Palestina yang miskin yang dihalau dari negerinya, mereka hidup dalam Pedesaan yang nyaman. $^{7}$ Meskipun dibesarkan dalam keadaan yatim dan dalam keluarga yang miskin, tidak menjadikan beliau merasa rendah diri apalagi malas. Sebaliknya, beliau bahkan giat mempelajari hadits dari ulama-ulama hadits yang banyak (Jakarta: Ichtiar Baru Van Hoeve, 1993), Cet. 1, hlm. 326.

7)Ahmad asy-Syurbasi, "Al-Aimatul Arba"ah", terj Sabil Huda, Sejarah dan Biografi Imam Empat Madzhab, (Jakarta: Bumi Aksara, 1993), hlm. 142 terdapat di Makkah, ${ }^{8}$ beliau terpaksa mengumpulkan batu-batu yang baik, belulang, pelepah kurma dan tulang unta untuk ditulis di atasnya, kadangkala beliau pergi ke tempattempat perkumpulan orang banyak meminta kertas untuk menulis pelajarannya. ${ }^{9}$

\section{Pendidikan dan pengalaman Imam Syafi'i}

Akibat kondisi ekonomi keluarga yang tidak mencukupi, pendidikan Syafi' $i$ tersia-sia. Ia kurang mendapatkan perhatian yang serius dari gurunya. Untungnya anak ini cerdas, pelajaran yang diberikan gurunya dengan mudah di serap dengan baik tidak jarang ia mengajarkan ilmu yang diperolehnya kepada temantemannya begitu guru mereka meninggalkan kelas, berkat kepandaian dan kebaikan Imam

8)Muhammad Jawad Mughniyah, "Al-Fiqh ,ala alMadzahib al-Khamsah", terj. Masykur, Fiqih Lima Madzhab, (Jakarta: Lentera Basritama, 2000), hlm. 29.

9)Ahmad asy-Syurbasi, op. cit., hlm. 143. 
Syafi'i seperti itu, ia dibebaskan dari biaya sekolahnya, keadaan ini berlangsung sampai ia hafal alQur"ean, waktu itu usianya baru sekitar tujuh sampai sembilan tahun. ${ }^{10}$ Begitu tamat belajar, Imam Syafi'i oleh ibunya dimasukkan ke lembaga pendidikan lain yang berada dalam Masjid Haram, agar dapat membaca Alqurean lebih baik termasuk tajwid dan tafsirnya, dalam usia 13 tahun, Syafi'i sudah mampu membaca al-Qur'an dengan tartil dan baik, sudah dapat menghafalnya bahkan mampu memahami apa yang dibacanya sebatas kesanggupan seorang anak yang baru berusia 13 tahun. ${ }^{11}$ Ia membaca al-Qur'an dengan suara yang merdu dan tartil, ia benar-benar khusyue dicekam perasaan sedih bercampur perasaan takut kepada Alloh SWT. Disaat sedang membaca al-Qur'an di Masjid Haram, banyak orang yang

10)Abdullah Mustofa al-Maraghi, Fath al-Mubin di tabaqat al- Usuliyyin, terj. Husein Muhammad, Pakar-pakar Fiqh Sepanjang Sejarah, (Yogyakarta: LKPSM, 2001), Cet 1, hlm. 93. 11)Abdurarrahman asy-Syarkawi, Aimmah al-Fiqh atTi "ah", terj.H.M.H. al-Hamid al-aHusaini, Riwayat Sembilan Imam Fiqih, (Bandung: Pustaka Hidayah, 2000), hlm. 383. mendengarnya duduk bersimpuh di depannya, bahkan adapula yang meneteskan air mata karena terpukau mendengar suaranya yang merdu, bila Syafi'i melihat kejadian seperti itu ia berhenti membaca. ${ }^{12}$ Setelah dapat menghafal isi al-Qur'an dengan lancar, Syafi'i berangkat ke Dusun Badui, untuk mempelajari Bahasa Arab yang asli dan fasih, di sana selama bertahun-tahun Syafi' $i$ mendalami bahasa dan adat istiadat Arab yang asli, bahkan ketekunan dan kesanggupannya, Syafi' $i$ kemudian dikenal sangat ahli dalam bahasa Arab. ${ }^{13}$

Di samping itu untuk mendalami bahasa Arab ia pergi ke Kabilah Hudzail yang tinggal di pedusunan untuk mempelajari bahasa Arab yang fasih. Sepuluh tahun lamanya Imam Syafi'i tinggal di Badiyah itu, mempelajari syair, sastra dan sejarah. Ia terkenal ahli dalam bidang syair yang digubah golongan Hudzailitu, indah susunan

12) Ibid.

13) Dewan Redaksi Ensiklopedi Islam, Ensiklopedi Islam, (Jakarta: Ichtiar Baru Van Hoeve, 1993), hlm. 326. 
bahasanya. Di sana pula beliau belajar memanah dan mahir dalam bermain panah. Dalam masa itu Imam Syafi'i menghafal al-Qur"an, menghafal hadits, mempelajari sastra Arab dan memahirkan diri dalam mengendarai kuda dan meneliti keadaan penduduk-penduduk Badiyah dan penduduk-penduduk kota.

Imam Syafi'i belajar pada ulama-ulama Makah, baik pada ulama-ulama fiqih, maupun ulamaulama hadits, sehingga ia terkenal dalam bidang fiqh dan memperoleh kedudukan yang tinggi dalam bidang itu. Gurunya Muslim Ibn Khalid AzZamzi, mengajukan supaya Imam Syafi'i bertindak sebagai mufti. Sungguhpun ia telah memperoleh kedudukan yang tinggi namun beliau terus mencari ilmu. Sampai kabar kepadanya bahwa di Madinah ada seorang ulama besar yaitu Malik, yang memang pada masa itu terkenal dimana-mana dan mempunyai kedudukan tinggi dalam bidang ilmu dan hadits. Imam Syafi'i ingin pergi belajar kepadanya, akan tetapi sebelum pergi ke Madinah beliau lebih dahulu menghafal alMuwatha", susunan Malik yang telah berkembang pada masa itu. Kemudian beliau berangkat ke Madinah untuk belajar kepada Malik dengan membawa sebuah surat dari gubernur Makah. Mulai ketika itu beliau memusatkan perhatian mendalami fiqh di samping mempelajari al-Muwatha". Imam Syafi'i mengadakan mudarasah dengan Malik dalam masalahmasalah yang difatwakan Malik. Di waktu Malik meninggal tahun $179 \mathrm{H}$, Imam Syafi'i telah mencapai usia dewasa dan matang. ${ }^{14}$

Imam Syafi'i menerima fiqh dan hadits dari banyak guru yang masing-masingnya mempunyai manhaj sendiri dan tinggal di tempat-tempat berjauhan bersama lainnya. Ada diantara gurunya yang mu"tazili yang memperkatakan ilmu kalam yang tidak disukainya. Dia mengambil yang perlu diambil dan

14)Hasbi Ash Shiddieqy, Pokok-pokok Pegangan Imam Madzhab, (Semarang: PT Pustaka Rizki Putra,1997), hlm. 480-481. 
meninggalkan yang perlu ditinggalkan. Imam Syafi'i menerima ilmunya dari ulama-ulama Makah, ulama- ulama Madinah, ulama-ulama Iraq dan ulama-ulama Yaman. ${ }^{15}$

\section{Karya-karya Imam Syafi'i}

Menurut Abu Bakar alBaihaqy dalam kitab Ahkam alQur'an, bahwa karya Imam Syafi'i cukup banyak, baik dalam bentuk risalah maupun dalam bentuk kitab. Al-Qadhi Imam Abu Hasan Ibn Muhammad al-Maruzy mengatakan bahwa Imam Syafi'i menyusun 113 buah kitab tentang tafsir, fiqih, adab dan lain-lain. ${ }^{16}$

Adapun kitab-kitab karangan Imam Syafi'i pada umumnya dibagi kepada dua bagian. Pertama, yang diajarkan kepada murid-murid beliau selama beliau berada di Makah dan di Baghdad. Kumpulan kitab-kitab ini berisi Qaul al-Qadim yaitu pendapat Imam Syafi'i sebelum beliau pergi ke

\footnotetext{
15)Abdullah Musofa al-Maraghi, op. cit., hlm. 97.

16)Huzaimah Tahido Yanggo, Pengantar Perbandingan Madzhab, (Jakarta: Logos Wacana Ilmu, 1997), hlm. 120.
}

Mesir. Kedua, yang diajarkan kepada murid-murid beliau selama beliau mengajar di Mesir. ${ }^{17}$ Kitab-kitab karya Imam Syafi'i dibagi oleh ahli sejarah menjadi dua bagian:

a. Ditulis oleh Imam Syafi'i sendiri, seperti : al-Umm dan al- Risalah (riwayat al-Buwaiti dilanjutkan oleh Rabi Ibn Sulaiman)

b. Ditulis oleh murid-muridnya, seperti seperti Mukhtasyar oleh al-Muzanni dan Mukhtasyar oleh al-Buwaiti (keduanya merupakan ikhtisar dari kitab Imam Syafieci: al-Imla dan alAmaly). ${ }^{18}$

Kitab-kitab Imam Syafi'i, baik yang ditulisnya sendiri, didiktekan kepada muridnya, maupun dinisbatkan kepadanya, antar lain sebagai berikut:

a Kitab al-Risalah, tentang Ushul Fiqih (riwayat rabi), kitab al-Risalah adalah kitab yang pertama dikarang Imam

17)Muslim Ibrahim, Pengantar Fiqh Muqaran, (Jakarta: Erlangga, 1991), hlm. 94-95.

18) Hasbi ash-Shiddieqy, op. cit., hlm. 134. 
Syafi'i pada usia muda. Kitab ini ditulis atas permintaan Abd. Al-Rahman Ibn Mahdy di Makah.

b. Kitab al-Umm, sebuah kitab fiqih yang di dalamnya dihubungkan pada sejumlah kitabnya.

1) Kitab Ikhtilaf Abi Hanifah wa Ibn Abi Laila

2) Kitab Khila Ali wa Ibn Mas'ud, sebuah kitab yang menghimpun permasalahan yang diperselisihkan antara Ali dengan Ibn Masecud dan antara Imam Syafi'i dengan Abi Hanifah.

3) Kitab Ikhtilaf Malik wa alSyafi'i

4) Kitab Jama'i al-Ilmi

5) Kitab al-Rada „Ala Muhammad Ibn al-Hasan

6) Kitab Siyar al-Auza'iy

7) Kitab Ikhtilaf al-Hadits

8) Kitab Ibthalu al-Istihsan.

9) Kitab al-Musnad, berisi hadits-hadits yang terdapat dalam kitab al-Umm yang dilengkapi dengan sanadsanadnya.

10) Al-Imla

11) Al-Amaly

12) Harmalah (didiktekan kepada muridnya yang bernama Harmalah Ibn Yahya)

13) Mukhtasar al-Muzaniy (dinisbatkan kepada Imam Syafi'i)

14) Mukhtasar al-Buwaithiy (dinisbatkan kepada Imam Syafi'i)

15)Kitab Ikhtilaf al-Hadits (penjelasan Imam Syafi' $i$ tentang hadits-hadits Nabi SAW). ${ }^{19}$

Ada beberapa risalah dan karangan-karangan beliau baik yang dikarang langsung atau tidak langsung, tetapi belum pernah dicetak atau belum dicetak kembali. ${ }^{20}$ Imam Syafi'i menghembuskan nafasnya yang terakhir sesudah shalat Isyaee, malam Jumeat bulan Rajab tahun 204 H./819 M. dengan disaksikan muridnya Rabi al-Jizi.

19) Huzaimah Tahido, op. cit., hlm. 133. 20) Muslim Ibrahim, op. cit., hlm. 96. 


\section{Pembentukan Madzhab Syafi'i}

Berdasarkan sejarahnya, madzhab Syafi'i lahir setelah melalui persiapan yang panjang. Pada awalnya, Imam Syafi'i tampil sebagai seorang tokoh ahl al-hadits yang diperolehnya dari Imam Malik, kemudian ia juga menjadi tokoh ahl $a l-r a ' y i$ setelah bertemu dengan salah seorang ulama' madzhab Hanafi yaitu Muhammad bin al-Hasan alSyaibani.

Sejarah pertumbuhan dan perkembangan madzhab Syafi'i ini dibagi menjadi empat periode, yaitu periode persiapan, periode pertumbuhan yang ditandai dengan lahirnya madzhab al-Qadim, periode kematangan dan kesempurnaan pada madzhab al-Jadid, dan periode pengembangan dan pengayaan.

a. Periode Persiapan

Persiapan bagi lahirnya madzhab Syafi'i berlangsung sejak wafatnya Imam Malik tahun
$179 \mathrm{H}$, tepatnya ketika al-Syafi' $i$ berangkat ke Yaman untuk bekerja. Selama di Yaman, alSyafi'i bertemu dengan beberapa tokoh terkemuka, salah satunya adalah tokoh utama madzhab Hanafi (ahl al-ra yi) yaitu Muhammad bin al-Hasan alSyaibani. $^{21}$

Setelah mengenal madzhab Maliki (ahl al-hadits) dan madzhab Hanafi (ahl al-ra yi), Imam Syafi'i berusaha mengomparasikan berbagai pendapat tokoh dari kedua aliran tersebut untuk mendapatkan sisi positif dan kelebihan berbagai metode ijtihadnya, kaidah-kaidah terbaik yang diperoleh dari perbandingan ini kemudian diolah dan dirumuskannya dalam suatu tatanan baru yang kemudian diletakkan sebagai dasar madzhabnya. ${ }^{22}$

21) Lahmuddin Nasution, Pembaruan Hukum Islam dalam Madzhab Syafi'i, (Bandung: PT. Remaja Rosdakarya, 2001), hlm. 48 .

22)Cik Hasan Bisri, Kerangka Berfikir Dalam Penelitian Hukum Islam dan Pranata Sosial, Makalah, disampaikan pada forum diskusi dosen fakultas Syari'ah, Tanggal 16 Mei, (Bandung: IAIN SGD,1998), hlm. 22. 
b. Periode Pertumbuhan (Qaul al-Qadim)

Periode pertumbuhan madzhab Syafi'i ditandai oleh kedatangan Imam Syafi'i ke Baghdad untuk memperkenalkan konsep fiqihnya secara utuh, lengkap dengan kaidah-kaidah umum dan pokok-pokok pikiran yang siap untuk dikembangkan.

$$
\text { Upaya untuk }
$$

memperkenalkan madzhabnya ini dilakukan dengan cara menggelar majelis pengajian. Banyak ulama dengan latar belakang dan keahlian yang berbeda (ahli fiqih, hadis, bahasa dan sastra) hadir di majelis tersebut, dan mereka merasa puas atas pernyataan yang disampaikan oleh Imam Syafi'i. Dari sini tampaklah bahwa tingkat keilmuan Imam Syafi'i berada di atas mereka. Dengan demikian, namanya menjadi harum dan tersohor ke seluruh penjuru, pada akhirnya madzhabnya dapat diterima dan tersebar luas di tengah-tengah masyarakat Baghdad. ${ }^{23}$

Pendapat dan fatwa-fatwa fiqih yang dikemukakannya pada periode ini dikenal dengan sebutan qaul qadim. Selama kurang lebih dua tahun berada di Baghdad, ia berhasil menyusun dan mendiktekan kitab ar- Risalah dalam bidang ushul fiqih dan alHujjah dalam bidang fiqih. Kitab al-Hujjah inilah yang menjadi rujukan bagi qaul qadim alSyafi'i yang selanjutnya diriwayatkan oleh beberapa murid yang belajar kepadanya di Baghdad.

Pendapat dan fatwa-fatwa fiqih yang dikemukakannya pada periode ini dikenal dengan sebutan qaul qadim. Selama kurang lebih dua tahun berada di Baghdad, ia berhasil menyusun dan mendiktekan kitab ar- Risalah dalam bidang ushul fiqih dan alHujjah dalam bidang fiqih. Kitab al-Hujjah inilah yang menjadi rujukan bagi qaul qadim al- 
Syafi'i yang selanjutnya diriwayatkan oleh beberapa murid yang belajar kepadanya di Baghdad. ${ }^{24}$

c. Periode Kematangan dan Kesempurnaan (Qaul alJadid)

Setelah berhasil memperkenalkan madzhabnya di Baghdad, kemudian Imam Syafi' i pindah ke Mesir. Terdapat banyak pendapat yang berbeda-beda terkait perpindahan Imam Syafi' $i$ ke Mesir, namun yang lebih logis adalah pendapat Abdul Halim alJundi bahwa Imam Syafi'i mendengar kabar di Mesir terdapat dua kelompok yang prokontra, yaitu kelompok madzhab Hanafi dan kelompok madzhab Maliki. Ketika itu Imam Syafi'i berkata: "Saya berharap akan datang ke Mesir dan membawakan sesuatu yang akan membuat mereka tertarik sehingga tidak mempersoalkan kedua madzhab itu lagi. ${ }^{25}$

Kesimpulannya adalah Imam Syafi'i pindah ke Mesir karena mempunyai kepentingan pengembangan ilmu pengetahuan. Sebagai seorang ulama besar, ia merasa terpanggil untuk mengembangkan ilmu serta mempersatukan ahl al-ra'yi dan ahl al-hadits sekaligus memperkenalkan madzhabnya yang merupakan sintesa dari kedua aliran tersebut.

Selama di Mesir, Imam Syafi'i senantiasa sibuk dengan kegiatan- kegiatan yang bersifat produktif dan inovatif tentang fiqih dan akhirnya membuat kehujjahan serta kepribadian alSyafi'i sebagai seorang imam semakin riil. Karena berbagai alasan ilmiah, ia menyatakan ruju', yaitu meninggalkan beberapa pendapat lama yang telah dikemukakan di Baghdad dan mengubahnya dengan fatwafatwa yang baru (qaul jadid). 
d. Periode Pengembangan dan Pengayaan

Periode ini berlangsung sejak wafatnya Imam Syafi'i sampai dengan abad ketujuh. Murid-murid Imam Syafi' $i$ (thabaqat) yang telah mencapai derajat ijtihad dalam keilmuannya terus melakukan istinbath hukum untuk menghadapi masalahmasalah yang timbul pada masa mereka.

Mereka juga melakukan peninjauan kembali terhadap fatwa-fatwa imamnya. Dalil-dalil yang mendukung setiap fatwa mereka diperiksa kembali untuk menguatkan suatu hukum. Dalam setiap hal Imam Syafi'i selalu memberikan dua atau lebih fatwa yang berbeda, kemudian mereka melakukan tarjih setelah menelusuri dalilnya masingmasing untuk mendapatkan pilihan terkuat.

Mereka inilah yang kemudian memainkan peran penting dalam membela, melengkapi dan menyebarkan madzhab Syafi'i, sehingga mereka dapat hidup berdampingan atau bersaing dengan madzhab- madzhab lainnya di hampir semua wilayah Islam. Selain ramai dengan kegiatan istinbath, kajian dan diskusi antar sesamanya atau antara mereka dengan ulama dari madzhab lain, para ulama Syafi'iyah pada periode ini juga banyak menghasilkan karya tulis.

Hampir setiap ulama terkemuka menuangkan ilmunya dalam berbagai tulisan, berupa kitab, risalah, ta'liq, matan, mukhtashar, ataupun syarh, sesuai dengan metode penulisan yang berkembang pada masanya. Dengan demikian, semakin lama semakin kayalah madzhab tersebut dengan kitab-kitab. ${ }^{26}$ 
5. Metode Istinbath Hukum Imam Syafi'i

\section{a. Dalil muttafaq yang (disepakati)}

Dalam mengistinbathkan (mengambil dan menetapkan) suatu hukum, Imam Syafi'i memakai empat dasar yaitu: alQuran, al-Sunnah, Ijma' dan qiyas. Hal ini sesuai dengan yang disebutkan dalam kitabnya, alRisalah sebagai berikut:

$$
\begin{aligned}
& \text { لبس لأحد يقوم أبدا في شيء : حل أو حرم } \\
& \text { إلا من جهة العلم وجهة الخبر أو السنة أو الو } \\
& \text { الإجماع أو القياس }
\end{aligned}
$$

Artinya: Tidaklah seorang mengatakan dalam hukumselamanya ini halal, ini haram kecuali kalau ada pengetahuan tentang itu. Pengetahuan itu adalah kitab suci al-Qur"an, al-Sunnah, alIjma', dan al- Qiyas. ${ }^{27}$

Adapun penjelasan dari masing-masing pokok pegangan yang digunakan Imam Syafi'i dalam membina madzhabnya adalah sebagai berikut:

1) Al-Qur'an

Al-Qur'an adalah lafadz
Arab yang diturunkan kepada Sayyidina Muhammad SAW. Untuk direnungkan dan diingat, yang diriwayatkan secara mutawatir. Mulai dengan surat al-Fatihah dan diakhiri dengan surat al-Nas bahasa Arab adalah bagian dari keaslian, terjemahanya tidak dikatakan al-Qur'an sehingga apabila seseorang membaca terjemahnya dalam sholatnya tidaklah sah. ${ }^{28}$

Para ulama sepakat menetapkan bahwa al-Qur'an adalah sumber pertama segala sumber hukum Islam. Mereka berselisih pendapat, hanya tentang kedudukan al-Sunnah, apakah dia dapat mendatangkan hukum-hukum yang tidak ada pokoknya dalam al-Qur'an ataukah tidak, Imam Syafi'i menegaskan bahwa al-sunnah berhak mendatangkan hukum yang tidak ada pokoknya dalam

28 Syekh Muhammad al-Khudhori Biek. Ushul Fiqh, terj. Zaid H. al- Hamid, (Pekalongan Raja Murah, 1992), hlm. 50. 
al-Qur'an. ${ }^{29}$

Imam Syafi'i mengkaji al-Qur'an secara mendalam dan mengklasifikasikan ayat-ayat alQur'an ke dalam bentuk 'amm dan khas, beliau juga mengatakan bahwa di dalam alQurean ada pernyataanpernyataan tertentu yang bersifat umum di dalam alQur'an yang mengandung sebagai pernyataan 'amm dan khas. $^{30}$ Karena kedudukan alQur'an itu sebagai sumber utama dan pertama bagi penetapan hukum, maka apabila seseorang ingin menemukan hukum suatu kejadian, tindakan pertama yang harus ia lakukan adalah mencari jawaban penyelesaian dari al-Qur'an, selain hukumnya dapat disesuaikan dengan al-Qur'an maka ia tidak boleh mencari jawaban lain di luar al-Qur'an. ${ }^{31}$

2) Sunnah

29) Hasbi ash-Shiddieqy, op. Cit., hlm. 277.

30) Muhammad bin Idris Syafiei, op. Cit, hlm. 25

31)Amir Syarifudin, Ushul Fiqh, Jakarta: Logos Wacana Ilmu, 1997, hlm. 73.
Sandaran kedua dari madzhab Syafi'i adalah sunnah. Menurutnya orang tidak mungkin berpindah dari sunnah selama sunnah masih ada, mengenai hadits ahad, Imam Syafi'i tidak mewajibkan syarat kemasyhuran sebagaimana yang berlaku pada madzhab Hanafi. Tidak pula mewajibkan persyaratan yang ditetapkan oleh Imam Maliki, yaitu harus ada perbuatan yang memperkuatnya. Menurut Imam Syafi'i hadits itu sendiri tanpa lainnya sudah dianggap cukup, baginya hadits ahad tidak masalah untuk dijadikan sandaran, selama yang meriwayatkannya dapat dipercaya, teliti, dan selama hadits itu muttasil (sanadnya bersambung) kepada

Rasulullah. Jadi beliau tidak mengharuskan hanya mengambil hadits mutawatir saja.

Imam Syafi'i dalam 
menerima hadits ahad

mensyaratkan sebagai berikut:

a) Perawinya terpercaya, ia tidak menerima hadits dari orang yang tidak terpercaya.

b) Perawinya berakal, memahami apa yang diriwayatkannya.

c) Perawinya dhabit (kuat ingatannya)

d) Perawinya benar-benar mendengar sendiri hadits itu dari orang yang menyampaikan kepadanya.

e) Perawi itu tidak menyalahkan para ahli ilmu yang juga meriwayatkan hadits itu. $^{32}$

Imam Syafi'i menempatkan as-sunnah sejajar dengan al-Qur'an, karena menurut beliau, sunnah itu menjelaskan al-Qur'an dan hadits mutawatir. Disamping itu, al-Qur'an dan sunnah keduanya adalah wahyu,

32) Huzaemah Tahido Yanggo, op. cit, hlm. 129 meskipun kekuatan sunnah secara terpisah tidak sekuat seperti al- Qur'an. ${ }^{33}$

Mengenai kedudukan assunnah Imam Syafi'i mengungkapkan bahwa kedudukan sunnah terhadap alQur'an adalah sebagai berikut: ${ }^{34}$

1) Menerangkan kemujmalan al-Qur'an, seperti menerangkan kemujmalan ayat tentang shalat dan puasa. Menerangkan khash al-Qur'an yang dikehendaki 'amm dan 'amm yang dikehendaki khas.

2) Menerangkan hukumhukum yang tidak ada dalam al- Qur'an.

3) Ijma'

Jumhur ulama

berpendapat, bahwa

kedudukan ijma' menempati salah satu sumber dalil hukum sesudah al-Qur'an dan sunnah, berarti ijma' dapat menetapkan hukum yang

33) Ibid., hlm. 128.

34) Hasbi ash-Shiddieqy, op. cit., hlm. 250-251. 
mengikat dan wajib dipatuhi umat Islam bila tidak ada ketetapan hukumnya dalam al-Qur'an maupun sunnah, untuk menguatkan pendapatnya ini jumhur mengemukakan beberapa ayat al-Qur'an diantaranya adalah surat an-Nisa ayat $115,{ }^{35}$ adalah sebagai berikut:

4) Qiyas

Dari segi bahasa, qiyas ialah mengukur sesuatu atas lainnya dan mempersamakannya. ${ }^{36}$

Sedangkan menurut istilah ahli ushul ialah:

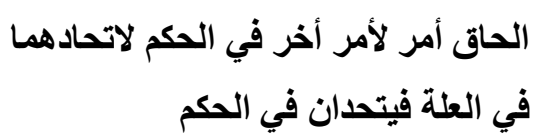

Artinya: "Menghubungkan hukum sesuatu pekerjaan kepada orang lain, karena kedua pekerjaan itu sebabnya sama yang menyebabkan hukumnya juga sama.'

Sesuai dengan ta'rif tersebut di atas, apabila ada

35) Amir Syarifuddin, loc. Cit.

36) Hanafie, Ushul Fiqh, Jakarta: Widjaya, 1989, hlm. 128. suatu peristiwa yang hukumnya telah ditetapkan oleh suatu nash dan illat hukumnya telah diketahui menurut satu cara dari cara-cara mengetahui illat-illat hukum, kemudian didapatkan suatu peristiwa lain yang hukumnya adalah sama dengan illat hukum dari peristiwa yang sudah mempunyai nash tersebut, maka peristiwa yang tidak ada nashnya ini disamakan dengan hukum peristiwa yang ada nashnya, lantaran adanya persamaan illat hukum pada kedua peristiwa itu tidak akan ada sekiranya tidak ada illatillatnya. $^{37}$

Pendirian Imam Syafi'i tentang hukum qiyas sangat hati-hati dan sangat keras, karena menurutnya qiyas dalam soal-soal keagamaan itu tidak begitu perlu diadakan kecuali jika memang keadaan memaksa, 
berikut beberapa perkataan beliau tentang hukum qiyas. ${ }^{38}$

a) Imam Ahmad Ibn Hambal pernah berkata: "Saya pernah berkata kepada Imam Syafi'i tentang hal qiyas, maka beliau berkata: "Di kala keadaan darurat." Artinya, bahwa beliau mengadakan hukum secara qiyas jika memang keadaan memaksa.Imam Syafi'i pernah berkata: "Saya tidak akan meninggalkan hadits Rasul karena akan memasukkan hukum qiyas, dan tidak ada tempat bagi qiyas beserta sunnah Rasulullah.”

b) Selanjutnya beliau berkata: "Tiap-tiap sesuatu yang menyalahi perintah Rasulullah tentulah jatuh dengan sendirinya dan tidak akan dapat berdiri tegak, juga qiyas tidak akan dapat tegak selama ada sunnah.”

38)Muctar Yahya, Dasar-dasar Pembinaan Hukum Fiqh Islami, (Bandung: al-Maarif, 1997), hlm. 66.
Selain daripada itu hukum qiyas yang terpaksa diadakan adalah hukum-hukum yang tidak mengenai urusan ibadah, yang pada pokoknya tidak dapat dipikirkan sebabsebabnya seperti, ibadah shalat dan puasa. Oleh karena itu beliau berkata: "Tidak ada qiyas dalam hubungan ibadah karena sesuatu yang berkaitan dengan urusan-urusan ibadah itu telah cukup sempurna dari al-Qur'an dan as-Sunnah." 39

Dari uraian di atas dapat diambil kesimpulan, bahwa cara Imam Syafi'i mengambil atau mendatangkan hukum qiyas itu adalah sebagai berikut: ${ }^{40}$

a) Hanya yang mengenai urusan keduniaan atau muamalat saja.

b) Hanya yang hukumnya belum atau tidak didapati dengan jelas dari nash alQur'an atau dari hadits

39)Ali Hasan, Perbandingan Mazhab, (Jakarta: PT Raja Grafindo Persada, 2002), hlm. 209.

40) Ibid, hlm..210. 
yang shahih.

c) Cara beliau mengqiyas adalah dengan nash-nash yang tertera dalam ayatayat al-Qur'an dan dari hadits Nabi. Oleh sebab itu Imam Syafi'i tidak sembarangan

mendatangkan atau mengambil hukum qiyas dan beliau merencanakan beberapa peraturan yang rapi bagi siapa yang hendak beristidlal (mengambil) dengan cara qiyas, sebagai dalil penggunaan qiyas.

\section{HUKUMAN HAD BAGI SESEORANG YANG MENYETUBUHI WANITA AJNABIAH DUBUR MELALUI ULAMA PERSPEKTIF}

Hanafiah berpendapat bahwa laki - laki yang menyetubuhi wanita ajnabiah melalui dubur tidak dikenakan hukuman had, dikarenakan menyetubuhi wanita melalui dubur tidak sama seperti menyetubuhinya melalui qubul hal itu dikarenakan qubul adalah tempat yang dapat menghasilkan syahwat dan itu tidak didapati pada dubur. ${ }^{41}$

Namun tidak semua ulama kalangan hanafiah berpendapat seperti tersebut diatas, Abu yusuf dan Muhammad sahabat Imam Abu hanifah berpendapat bahwa laki - laki yang menyetubuhi wanita ajnabiah melalui dubur dikenakan hukuman had. Imam Sarkhasi dalam karyanya al - Mabsuth menyebutkan:

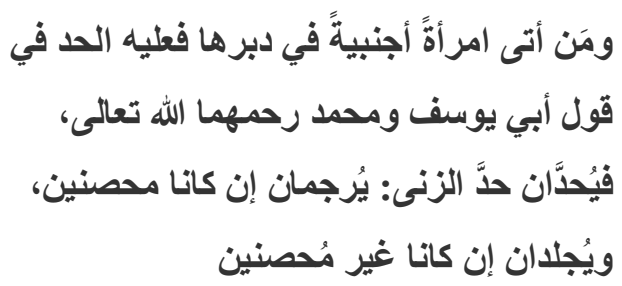

Artinya: Barang siapa menyetubuhi wanita asing melalui duburnya (si wanita) maka berlaku padanya hukuman had menurut pendapat Abu yusuf dan Muhammad rahmat Allah Swt kepada mereka berdua, maka berlaku bagi keduanya hukuman had zina: keduanya dirajam jika berstatus Muhshan (sudah menikah), dan dicambuk sebanyak seratus kali cambukan jika berstatus Ghairu muhshan. ${ }^{42}$

41)Amir Abdul Aziz, Fiqh al- Jina'I Fil Islam, (Cairo: Dar el- Salam, 2007), hlm. 246.

${ }^{42)}$ As-Sarkhasi, al-Mabsuth, (Beirut: Dar al - Ma'rifah, 1993), j. 4, hlm. 106. 
Malikiah, dan Hanabilah berpendapat bahwa laki - laki yang menyetubuhi wanita ajnabiah melalui dubur dikenakan hukuman had. Pengarang kitab al - Fiqhu a'la madzahibi al- 'arba'ah menyebutkan:

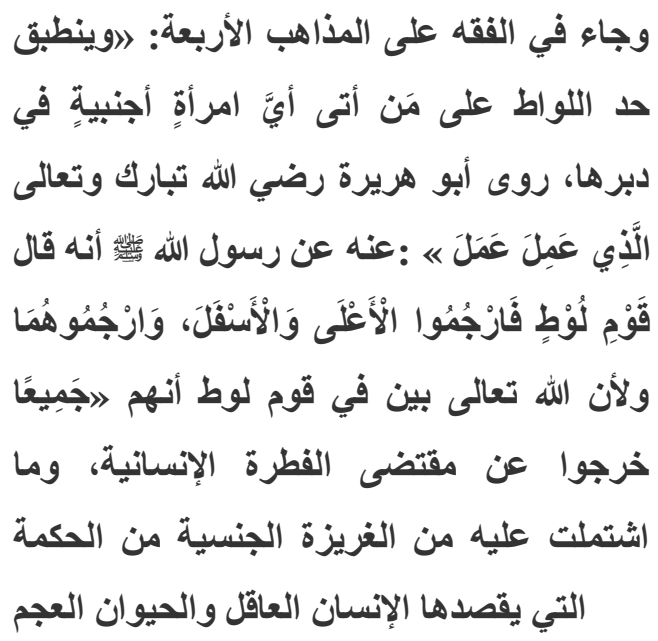

Artinya: diterapkan hukuman had bagi pelaku liwath bagi siapa saja yang menyetubuhi wanita melalui duburnya. Sejalan dengan sabda Rasulullah Saw yang diriwayatkan oleh Abu hurairah r.a : barang siapa yang melakukan apa yang dilakuakan kaum luth maka rajamlah bagian tubuh atas dan bawah serta rajamlah mereka berdua. Di dalam hadis ini allah menjelaskan melalui perantaraan lisan Rasul-Nya bahwa apa yang dilakukan kaum Luth adalah prilaku menyimpang yang keluar dari logika dan akal sehat serta bertolak belakang dari hikmah penciptaan manusia yang memiliki akal dan hal itulah yang membedakan manusia berakal dengan hewan ${ }^{43}$.

Zina yang dilakukan melalui qubul memiliki persamaan dengan perzinahan yang dilakukan melalui dubur. Dari segi nama, keduanya disebut dengan fahisyah (perbuatan keji), sedang dari segi makna: zina adalah sesuatu perbuatan yang bertujuan menciptakan syahwat dengan cara memasukkan kemaluan kedalam kemaluan wanita tanpa adanya kepemilikan dan syubhat, dan makna zina tersebut ditemukan pula pada persetubuhan atau perzinahan yang dilakukan melalui dubur. Karena keduanya menghasilakan syahwant dan keduanya pula merupakan bahagian tubuh yang harus ditutupi dan di jaga oleh seorang wanita.demikian pula wajib mandi bagi laki-laki yang memasukkan kemaluannya pasa salah satu dari keduanya (qubul dan

${ }^{43)}$ Abdurrahman bin Muhammad 'Iwadh, Fiqh 'Ala Madzahob al-'Arba'ah, (Beirut: Dar al - Kutub 'Ilmiah, 2003), j. 9, hlm. 77. 
dubur $)^{44}$. Dar ifta' mishriah mengeluarkan fatwa terkait laki - laki yang menyetubuhi wanita ajnabiah melalui dubur:

"اتيان المرأة في دبرها حرام شرعًا، وإن كان بين رجل وامر أة أجنبية فهو زنانًا لأن الآتيان في

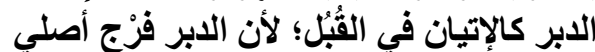
كالقبل، والزنا من الكبائر والمويقات المهلكات

Artinya: Menyetubuhi wanita melalui dubur haram hukmnya menurut syariat. Jika persetubuhan itu dilakukan seorang laki - laki kepada wanita ajnabiah maka perbuatan tersebut adalah perbuatan zina. Dikarenakan menyetubi wanita melalui dubur sama seperti menyetubuhi wanita pelalui qubul. Dubur adalah kemaluan sama seperti qubul dan zina merupakan salah satu dari pada dosa-dosa besar. ${ }^{45}$

\section{HUKUMAN HAD BAGI SESEORANG YANG MENYETUBUHI WANITA \\ AJNABIAH \\ MELALUI \\ DUBUR PERSPEKTIF \\ MADZHAB SYAFI'I}

Imam Syafii tidak

berpendapat secara langsung terkait persetubuhan yang dilakukan seorang

${ }^{44)}$ As - Sarkhasi, al - Mabsuth, j. 4, hlm. 106

${ }^{45)} \mathrm{http}$ ://www.daralifta.org/ar/ViewF atwa.aspx?sec=fatwa \&ID=13327 20 oktober 2019, pukul 13.40 WIB. laki - laki kepada wanita ajnabiah melalui dubur. Namun permasalahan ini ditanggapi oleh beberapa ulama di dalam madzhab syafi'iah:

1. Imam Mawardi berkata didalam kitabnya al-Hawi al - Kabir:

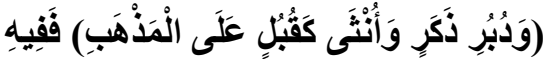

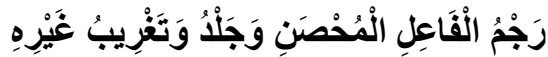

Artinya: (dan dubur laki - laki dan perempuan sama seperti qubul menurut pendapat madzhab (maka bagi pelaku yang melakukannya dihukum rajam jika muhshan (sudah menikah) dan dicambuk beserta diasingkan jika ghairu muhshan (belum menikah). ${ }^{46}$

Pengarang kitab qalyubi wa umairah berkata di dalam kitabnya:

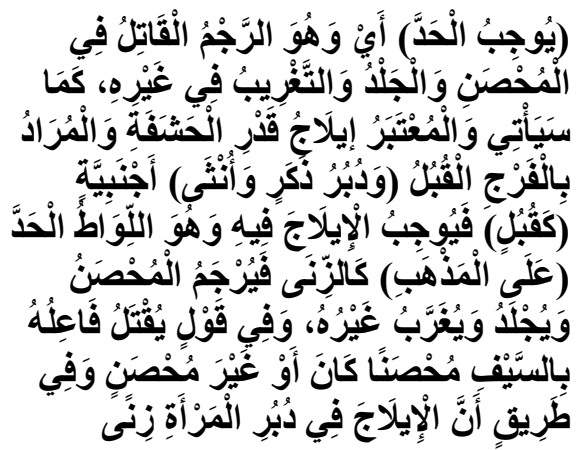

Artinya: (Diwajibkan human had) yaitu: rajam jika pelaku muhshan

46) Abu Hasan Ali bin Muhammad bin Muhammad, Hawi al - Kabir Fi Fiqh Madzahib al - Syafi'I, (Beirut: Dar el Kutub 'Ilmiah, 1999), j. 13, hlm. 221. 
dan cambuk beserta pengasingan jika sipelaku ghairu muhshan, sebagaimana pada pembahasan yang akan tiba pada pembahasan selanjutnya, dan hukuman tersebut berlaku jika memasukkan kadar kepala zakar, yang di,aksud dengan faraj disini adalah qubul (dan dubur laki laki dan wanita) yang bukan mahram (seperti qubul) maka diwajibkan padanya hukuman had karena hal itu merupakan liwath (menurut pendapat madzhab) hal yang demikian sama seperti zina maka pelakunya dirajam jika muhshan dan dicambuk beserta diasingkan jika ghairu muhshan. Dan adapula yang berpenda[at pelakunnya dibunuh dengan pedang baik muhshan ataupun ghairu muhshan dan bersetubuh melalui dubur adalah zina. ${ }^{47}$

\section{E. PENUTU}

Pada permasalahn ini Ulamaulama Syafi'iah berpendapat bahwa menyetubuhi wanita ajnabiah melalui dubur adalah haram dan posisinya sama seperti zina. Maka dengan demikian bagi siapa saja yang melakukannya dikenakan hukuman had sebagaimana hukuman had bagi

\footnotetext{
${ }^{47)}$ Ahmad Salamah al - Qalyubi dan Ahmad Barlasi 'Umairah, Qalyubi wa 'Umairah, (Beirut: Dar el - Fikr ', 1995), j. 4, hlm. 180.
}

pelaku zina, jika pelaku muhshan (sudah menikah) maka dihukum rajam, namun jika pelaku ghairu muhshan (belum menikah) maka dihukum cambuk sebanyak seratus kali cambukan beserta diasingkan.

Pendapat ini didasari oleh dalil qiyas. Dimana ulama Syafi'iah mengqiyas persetubuhan melalui dubur dengan persetubuhan melalui qubul. Zina yang dilakukan melalui qubul memiliki persamaan dengan perzinahan yang dilakukan melalui dubur. Dari segi nama, keduanya disebut dengan fahisyah (perbuatan keji), sedang dari segi makna: zina adalah sesuatu perbuatan yang bertujuan menciptakan syahwat dengan cara memasukkan kemaluan kedalam kemaluan wanita tanpa adanya kepemilikan dan syubhat, dan makna zina tersebut ditemukan pula pada persetubuhan atau perzinahan yang dilakukan melalui dubur ulama Syafi'iah mengqiyasnya dengan zina yang dilakukan melalui qubul. Qiyas menurut Syafi'iah adalah: Menghubungkan hukum sesuatu 
pekerjaan kepada orang lain, karena kedua pekerjaan itu sebabnya sama yang menyebabkan hukumnya juga sama. "Sesuai dengan ta"rif tersebut di atas, apabila ada suatu peristiwa yang hukumnya telah ditetapkan oleh suatu nash dan illat hukumnya telah diketahui menurut satu cara dari caracara mengetahui illat-illat hukum, kemudian didapatkan suatu peristiwa lain yang hukumnya adalah sama dengan illat hukum dari peristiwa yang sudah mempunyai nash tersebut, maka peristiwa yang tidak ada nashnya ini disamakan dengan hukum peristiwa yang ada nashnya, lantaran adanya persamaan illat hukum pada kedua peristiwa itu tidak akan ada sekiranya tidak ada illatillatnya. Sedangkan illatnya: Karena keduanya menghasilakan syahwant dan keduanya pula merupakan bahagian tubuh yang harus ditutupi dan di jaga oleh seorang wanita.demikian pula wajib mandi bagi laki - laki yang memasukkan kemaluannya pada salah satu dari keduanya (qubul dan dubur).

\section{DAFTAR PUSTAKA}


Abdullah Mustofa al-Maraghi, "Fath al-Mubin di tabaqat al- Usuliyyin"e, terj. Husein Muhammad, Pakar-pakar Fiqh Sepanjang Sejarah, Yogyakarta: LKPSM, 2001, Cet 1, h.93.

Abdurarrahman asy-Syarkawi, „Aimmah al-Fiqh at-Tis "eah”, terj.H.M.H. alHamid al-aHusaini, Riwayat Sembilan Imam Fiqih, Bandung: Pustaka Hidayah, 2000, h. 383.

Ahmad asy-Syurbasi, “Al-Aimatul Arba"eah”, terj Sabil Huda, Sejarah dan Biografi Imam Empat Madzhab, Jakarta: Bumi Aksara, 1993, h. 142

Ali Hasan, Perbandingan Mazhab, Jakarta: PT Raja Grafindo Persada, 2002, h. 209.

Cik Hasan Bisri, Kerangka Berfikir Dalam Penelitian Hukum Islam dan Pranata Sosial, Makalah, disampaikan pada forum diskusi dosen fakultas Syari'ah, tanggal 16 Mei, (Bandung: IAIN SGD,1998), 22.

Dewan Redaksi Ensiklopedi Islam, Ensiklopedi Islam, Jakarta: Ichtiar Baru Van Hoeve, 1993, Cet. 1, h. 326.

Hasbi Ash Shiddieqy, Pokok-pokok Pegangan Imam Madzhab, Semarang: PT Pustaka Rizki Putra,1997, h.480-481.

Huzaimah Tahido Yanggo, Pengantar Perbandingan Madzhab, Jakarta: Logos Wacana Ilmu, 1997, h. 120.

Jaih Mubarok, Modifikasi Hukum Islam Studi tentang Qaul Qadim dan Qaul Jadid, Jakarta: PT. Raja Grafindo Persada, 2002, h.27.

Jaih mubarok, Sejarah dan Perkembangan Hukum Islam, Bandung: PT Remaja Rosdakarya, 2000, h.101. Lihat juga Abdul Mun "im Saleh, Madzhab Syafi'i Kajian Konsep al-Maslahah, Yogyakarta: Ittaqa Press, 2001, h.7. Lihat juga Ali Fiqri, Kisah-kisah Para Imam Madzhab, Yogyakarta: Mitra Pustaka,2003, h.76 Lahmuddin Nasution, Pembaruan Hukum Islam dalam Madzhab Syafi'i, (Bandung: PT. Remaja Rosdakarya, 2001), 48. 
Mahmud Syalthut, Fiqih Tujuh Madzhab, terj. Abdullah Zakiy al- Kaaf, Bandung: cv Pustaka Setia, 2000, h.17.

Muctar Yahya, Dasar-dasar Pembinaan Hukum Fiqh Islami, Bandung: alMaarif, 1997, h. 66.

Muhammad bin Idris asy-Syafie ${ }^{\mathrm{e}}$, al-Risalah, Beirut: al-Maktabah alIlmiyyah, h.39.

Muhammad Jawad Mughniyah, “Al-Fiqh ,ala al-Madzahib al-Khamsah”, terj. Masykur, Fiqih Lima Madzhab, Jakarta: Lentera Basritama, 2000, h. 29.

Muslim Ibrahim, Pengantar Fiqh Muqaran, Jakarta: Erlangga, 1991, h. 9495.

Mustofa Muhammad asy-Syak"ah, "Islam bi Laa Madzzhib", Terj. A.M. Basamalah, Islam Tidak Bermadzhab, Jakarta: Gema Insani Press, 1994, h. 349.

Syekh Muhammad al-Khudhori Biek. Ushul Fiqh, terj. Zaid H. al- Hamid, Pekalongan Raja Murah, 1992, h. 50.

Teungku Muhammad Hasbi ash-Shiddieqy, Pengantar Hukum Islam, Semarang: Pustaka Rizki Putra, 1997, h. 200.

Zainudin Ali, Hukum Pidana Islam, Jakarta: Sinar Grafika, 2009, h. 37 